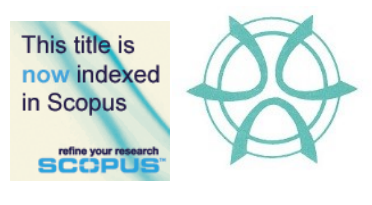

PLANNING MALAYSIA:

Journal of the Malaysian Institute of Planners

VOLUME 18 ISSUE 1 (2020), Page 133 - 144

\title{
STUDIES ON THE CULTURAL ECOSYSTEM SERVICES IN MALACCA CITY
}

\author{
Nur Shazwanie Rosehan ${ }^{1}$, Azlan Abas $^{2}$ \& Kadaruddin Aiyub ${ }^{3}$ \\ ${ }^{1,2,3}$ Centre of Social, Development \& Environmental Studies (SEEDS), \\ Faculty of Social Sciences and Humanities \\ UNIVERSITI KEBANGSAAN MALAYSIA
}

\begin{abstract}
The benefits from ecosystem services have the prospective and potential to improve the Malay urban design and increase the quality of life. However, rapid development and urbanization activities are increasingly causing a conversion from the original functions and changes that can affect the urban environment. This paper aims to update current understanding of the concept of Malay cultural ecosystem services in Malacca City. Quantitative research through the survey method to 150 Malay respondents have been carried out in order to identify the parameters describing the types and value of the Malay cultural ecosystem services in the city context. The result revealed aesthetic value, recreational, tourism, social relations, spiritual and educational as the most significance parameters of the Malay cultural ecosystem services. The paper concluded that only through good practices from all parties can reduce the incredible development effects as political, economic and social systems is inevitable and constantly generates new demand.
\end{abstract}

Keywords: Malay, urban design, ecosystem services, policies, Sustainable Development Goals, Environmental Management

${ }^{1}$ Postgraduate Student at Universiti Kebangsaan Malaysia. Email: nurshazwanierosehan88@gmail.com 
Nur Shazwanie Rosehan, Azlan Abas, Kadaruddin Aiyub

Studies on Malay Urban Ecosystem Services and Cultural in Malacca City

\section{INTRODUCTION}

The Malay city possesses a unique urban design and concept, as well as a unique architectural identity. Moreover, Malay urban is one of the oldest civilizations in the world. The urban design deals with both the aesthetic and functional aspects of the City's built environment. Aesthetics, being the traditional concern of the urban design can only be more meaningful when they are combined with other considerations to generate an environment that is visually pleasant, convenient, comfortable, which conveys a sense of place, pride and belonging (Dewan Bandaraya Kuala Lumpur, 2020). The Millennium Ecosystem Assessment (MEA) (2005) defines the ecosystem services as the advantages people obtain from the ecosystem and its surroundings. Ecosystem services are the goods given to humans throughout the conversions of environments such as water and vegetation into a flow of necessary services and goods such as food and clean air (Constanza et al. 1997). Therefore, it becomes important to understand the role of nature in maintaining human well-being including the Malay cities and Malay urban design.

Zhang et al. (2016) has categorized these direct and indirect ecosystem services into four categories to sustain human well-being and survival throughout the world. These are including the regulation (e.g., disease control and flood regulation, support (e.g., primary production and nutrient cycling), provisioning (e.g., freshwater and fiber) and cultural (e.g., recreational and spiritual reflection). The ecosystem service concept can be adapted to urban ecosystems because the services for various inhabitants are important and needed (Tratalos et al. 2007; Ahern, 2007). In this case, urban planning plus urbanization activities are often associated with the development potential of ecosystem services including in the Malay urban design. Therefore, its ecosystem services will also decrease. This is because an urban ecosystem will be worthless if it is unable to provide any basic benefit and human need.

The rising request and demand for space for new users in the associated residential and industrial areas have generated massive uncontrolled built-up areas that occur in many developing countries and developed cities (Gonzalez \& De Lazaro, 2011). Human activities can dominate the changes in land use and unnecessary synergies and trade-offs in the context of the ecosystem service's provision (Zhang et al. 2016). Sometimes, some of the old buildings carry a lot of traditional and unique identities in terms of history, architectural and heritage value which later reflected towards the urban form aspect (Abdullah et al. 2018). Hence, the contributions of the ecosystem services to the human well-being and world's economy have been recognized in policy and also in the basic science and policy (Egoh et al. 2012; Corbera, 2012; Van Oudenhoven et al. 2012; Muller and Burkhard, 2012).

Development and urbanization activities are increasing rapidly in the country, causing the conversion from the original land uses to other uses such as 
agricultural land to residential or industrial areas planning. Generally, this changes the physical environment consisting of either atmosphere, biosphere, lithosphere and even hydrosphere (Md Jahi, 1993). Changes that occur as a result of human activities can affect the human environment such as the impact on the well-being of people. Besides, measuring the quality and well-being of the population who received the impact of rapid development is too difficult for a community or individual. In this context, although there are no indicators or effective methods for measuring cultural service satisfaction and the well-being of the population, the rapid development activities in one area will certainly have a social impact on the population in particular.

Malay urban cities, such as Malacca City with the highest percentage of Malay population, consist of designated built that can accommodate urban ecosystem services in cultural categories. In this study's point of view, its only focused on the cultural categories of the Malay urban ecosystem services in the Malay city as concerned in recognizing the social quality and level, despite the fact that the Malay urban ecosystem services provided more than the services. The cultural services, which include the direct uses of non-material (Sarukhan and Whyte, 2003) also cause bad qualifications and consolidation in management terms (de Groot et. 2005). The study of ecosystems that researchers often deal with is related to cultural aspects such as social relations, recreation, tranquillity, culture, tourism and a host of other ecosystem services. Cultural-based ecosystem services are often included under the direct use values (Sarukhan \& Whyte, 2003) and undergo reduction and integration in management plans (de Groot et al., 2005). However, in Malaysia, little research has been done on contemporary history and culture as conducted by researchers in other ASEAN countries, namely Singapore.

Accordingly, Table 1.0 shows a matrix of lists of authors or researchers who have carried out research related to most of the urban ecosystem services conducted overseas. Based on these matrices, it is found that most researchers carry out studies on the urban ecosystem services for cultural categories. Besides, based on these matrices, cultural categories such as aesthetic values, spiritual values, education, recreation, tourism and social relations can often be useful in the context of urban ecosystem services. In this regard, among the researchers who conducted studies on the six cultural and social dimensions derived from urban ecosystems are Riechers et al. (2016) and Milcu et al. (2013). The table also shows that many researchers focus on cultural aspects as the results of their research will be considered in the planning and decision-making process of particular parties (Eliasson et al., 2019). Therefore, researchers wanted to measure cultural studies through some aspects of the Malay culture in the city of Malacca especially the level of social satisfaction in rapid development activities. 
Nur Shazwanie Rosehan, Azlan Abas, Kadaruddin Aiyub

Studies on Malay Urban Ecosystem Services and Cultural in Malacca City

Table 1: The matrix lists of authors

\begin{tabular}{|c|c|c|c|c|c|c|c|c|c|c|c|c|c|c|}
\hline Category & Dimension & 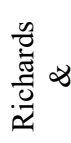 & 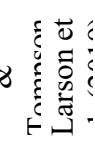 & 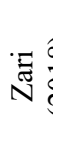 & 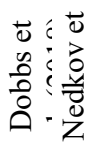 & $\begin{array}{l}1 \\
0 \\
0 \\
0 \\
0 \\
0 \\
0 \\
0\end{array}$ & 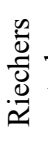 & $\frac{\sqrt{\pi}}{5}$ & $\begin{array}{l}\infty \\
\dot{\Delta} \\
\dot{0} \\
\dot{\omega}\end{array}$ & 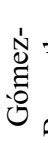 & 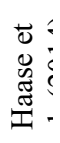 & 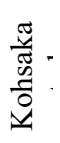 & 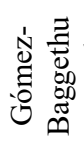 & 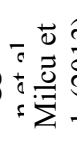 \\
\hline \multirow{6}{*}{ Cultural } & Aesthetic value & $\mathrm{x}$ & $\mathrm{X}$ & $\mathrm{x}$ & & $\mathrm{x}$ & $\mathrm{x}$ & $\mathrm{x}$ & $\mathrm{x}$ & $\mathrm{x}$ & $\mathrm{x}$ & & $x$ & $\mathrm{x}$ \\
\hline & Spiritual & & & $\mathrm{x}$ & & $\mathrm{x}$ & $\mathrm{x}$ & $\mathrm{x}$ & & & $\mathrm{x}$ & & & $\mathrm{x}$ \\
\hline & Educational & & & & & $\mathrm{x}$ & $\mathrm{x}$ & $\mathrm{x}$ & & & & $x$ & $x$ & $\mathrm{x}$ \\
\hline & Recreational & $\mathrm{x}$ & $X$ & $\mathrm{x}$ & $\mathrm{x}$ & $\mathrm{x}$ & $\mathrm{x}$ & $\mathrm{x}$ & $x$ & $x$ & & $x$ & $x$ & $\mathrm{x}$ \\
\hline & Tourism & & & & & $\mathrm{x}$ & $\mathrm{x}$ & & $\mathrm{x}$ & & $\mathrm{x}$ & & & $\mathrm{x}$ \\
\hline & Social relation & $\mathrm{x}$ & $X$ & $\mathrm{x}$ & & & $\mathrm{x}$ & $\mathrm{x}$ & & $\mathrm{x}$ & & & & \\
\hline
\end{tabular}

Furthermore, it is also important to achieve the Sustainable Development Goals by 2030 for a better and more sustainable future for all, including environmental degradation, peace and justice in order to leave no one behind. In order to determine the Malay urban ecosystem services and cultural in Malacca City this study aims to measure the value of the urban ecosystem services that have been provided based on the perception of the Malay communities. In addition, the researcher hope that this study will complement existing policy and help to design better conservation plan for the Malay urban ecosystem services and cultural in the area. Then, the paper also discusses about the methodology and approach that been used and also the results based on the study, as well as the discussion and conclusions. Hence, the researcher concludes this study by a brief overview role to make sure that the Malay urban, especially in Malacca and other cities in Malaysia, to be sustainable and more liveable with the right guideline in the present and future.

\section{METHODOLOGY}

The study was conducted around the city of Malacca with an area of 114.7 square miles $\left(303 \mathrm{~km}^{2}\right)$. Malacca City is a famous tourism city and it is administered by the Malacca City Council (Majlis Bandaraya Melaka Bersejarah, MBMB). Furthermore, the Malaysian Census in 2010 reported that the population of Malacca City was 484,885, which Malays comprised the majority ethnics with 273,844. Therefore, the study was conducted in Malay residential areas around the city such as Taman Pahlawan, Kampung Padang Temu, Kampung Melayu, Taman Sungai Udang and Kampung Kubu. The selection of the study area also includes the placement of the special Malay urban design elements around the study area especially building design and historical heritage that have their aesthetic value with the highest percentage of Malay population.

The data of this study were obtained from various primary and secondary sources. Point of view, primary data was collected through a survey form as its instrument. This survey is also conducted as a pilot study that used a 
purposive sampling method where the form was distributed only to 150 Malay respondents who live in and around Malacca City via door-to-door surveys. 150 respondents were sampled in the experimental group that focuses on the characteristics of the Malay respondents and it also withers away as a backup sample in these pilot studies. Furthermore, the survey forms were distributed to the respondents to measure their perception on the urban ecosystem services that are provided around them and also to measure the cultural level in their community's life. Besides, the secondary data are obtained from various sources including through the ministry's website and the Local Authority such as Majlis Bandaraya Melaka Bersejarah (MBMB).

\section{RESULTS}

\section{Respondent's Background}

Figure 1 shows the respondent's background in the sampling area around Malacca City.

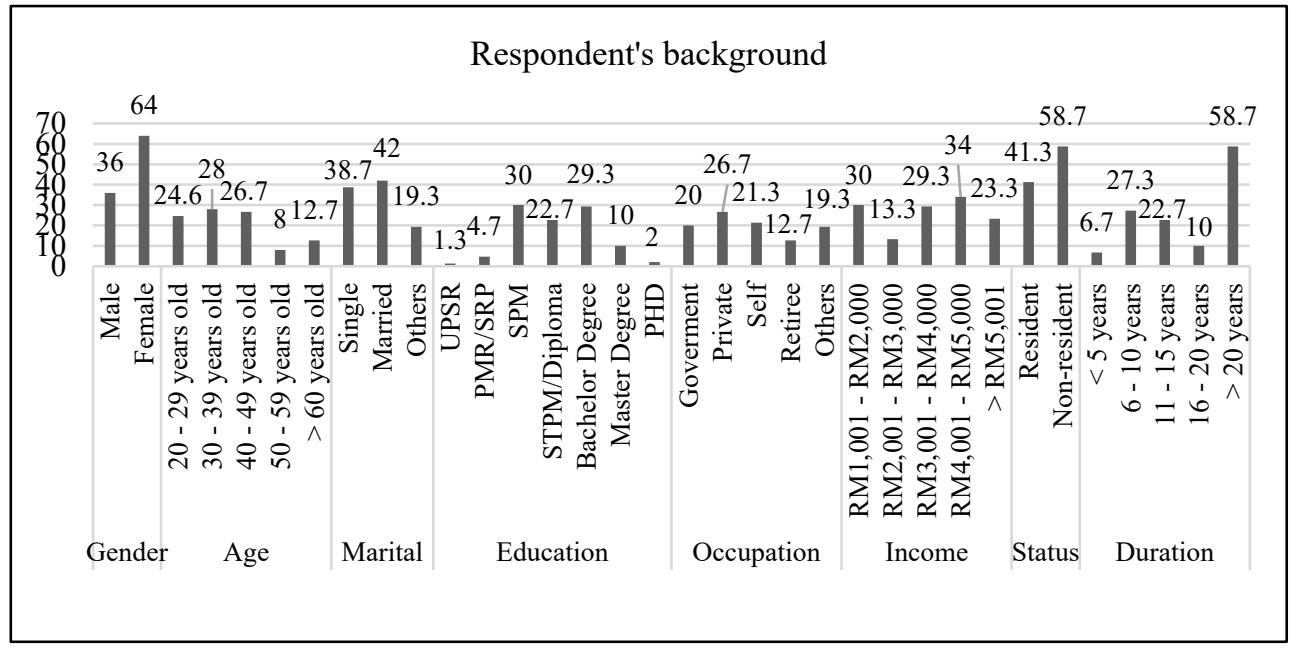

Figure 1: The respondent's background

Then, based on the survey that is distributed to 150 Malay respondents, $64 \%$ were females and $36 \%$ were males. In terms of age, it was divided into 6 age categories. The first category was under 19 years, that has no respondents, then 20-29 (24.6\%), 30-39 (28\%), 40-49 (26.7\%), 50-59 (8\%) and >60 years old (12.7\%). Besides, most of the respondents have a bachelor's degree (29.3\%), followed by SPM (30\%), PMR (4.7\%), PHD (2\%) and UPSR (1.3\%). For occupation background, most of the respondents work in the private sectors $(26.7 \%)$, followed by self-employed sectors, the government sectors $(20 \%)$, and the remaining were retirees $(12.7 \%)$. Next, in terms of residency status, where the 
Nur Shazwanie Rosehan, Azlan Abas, Kadaruddin Aiyub

Studies on Malay Urban Ecosystem Services and Cultural in Malacca City

original respondents from Malacca, or vice versa, most of them came from other areas or cities which were $58.7 \%$ and $41.3 \%$ were the original residence from Malacca. Most of the respondents have stayed in Malacca for more than 20 years and less than 5 years $(6.7 \%)$. Overall, majority of the respondents have lived for a long time in the city and keep productive to enjoy the Malay cultural and urban ecosystem service cycle there.

\section{Malay Urban Ecosystem Services Assessment}

Table 2 shows the respondent's perception on the urban ecosystem services that are offered around them from the survey data in Malacca City. All the urban ecosystem services were measured based on a Likert scale with 3 scores: offered, neutral and none-offered. The classification of urban ecosystem services was referred to as Millennium of Ecosystem Assessment (2005) and The Economics of Ecosystems and Biodiversity (2011); five services belong to regulating services, single service from supporting services and six services from cultural services. However, there is no service from provisioning services because its services were rare and none was offered directly in the urban ecosystem services as shown in Table 2 .

Table 2:Malay urban ecosystem services assessment in Malacca City

\begin{tabular}{llccc}
\hline & Categories & Offered & Neutral & None-offered \\
\hline Regulating & Climate regulation & 80 & 10 & 10 \\
& Flood regulation & 80 & 10 & 10 \\
& Disease control & 73.3 & 16.7 & 10 \\
& Carbon sequestration & 50 & 46.7 & 3.3 \\
& Noise pollution reduction & 33.3 & 53.3 & 20 \\
Supporting & Hydrology Cycle & 90 & 10 & 0 \\
Cultural & aesthetic value & 92 & 8 & 0 \\
& spiritual & 94.7 & 5.3 & 0 \\
& education & 100 & 0 & 0 \\
& recreation & 100 & 0 & 0 \\
& tourism & 100 & 0 & 0 \\
\hline
\end{tabular}

Based on the table, the majority of the respondents have agreed that Malacca City offered most of the cultural classifications; there is a $100 \%$ score respectively on educational, recreation, tourism and social relations. The supporting classifications show a $90 \%$ score on the hydrology cycle. Then, in term of regulating classifications, most of the respondents (80\%) agreed that Malacca City offered climate regulation and flood regulation category shows that $80 \%$ of the respondents agreed. Then, the disease control classification shows $73.3 \%$ of respondents agreed on the urban ecosystem services offered and the 
remaining $10 \%$ disagreed. Besides, based on the table, it also shows that most of the respondents $(50 \%)$ are neutral about the carbon sequestration that is offered at their areas and $46.7 \%$ of respondents agreed that the service is offered. In terms of noise pollution reduction, $53.3 \%$ of respondents are neutral that Malacca City has offered the services of noise pollution reduction, while the remaining 33.3\% of them agreed and $20 \%$ disagreed. Overall, based on the result, the most significance of the urban ecosystem services provided by classified them, including cultural services (aesthetic value, recreational, tourism, social relations, spiritual and educational).

\section{Assessment of Malay Urban Cultural in Malacca City}

Based on Figure 2, the study found that the overall cultural components; educational, aesthetic value, recreational, tourism, spiritual and social relations were in a satisfactory condition, which means that these services were provided in the city.

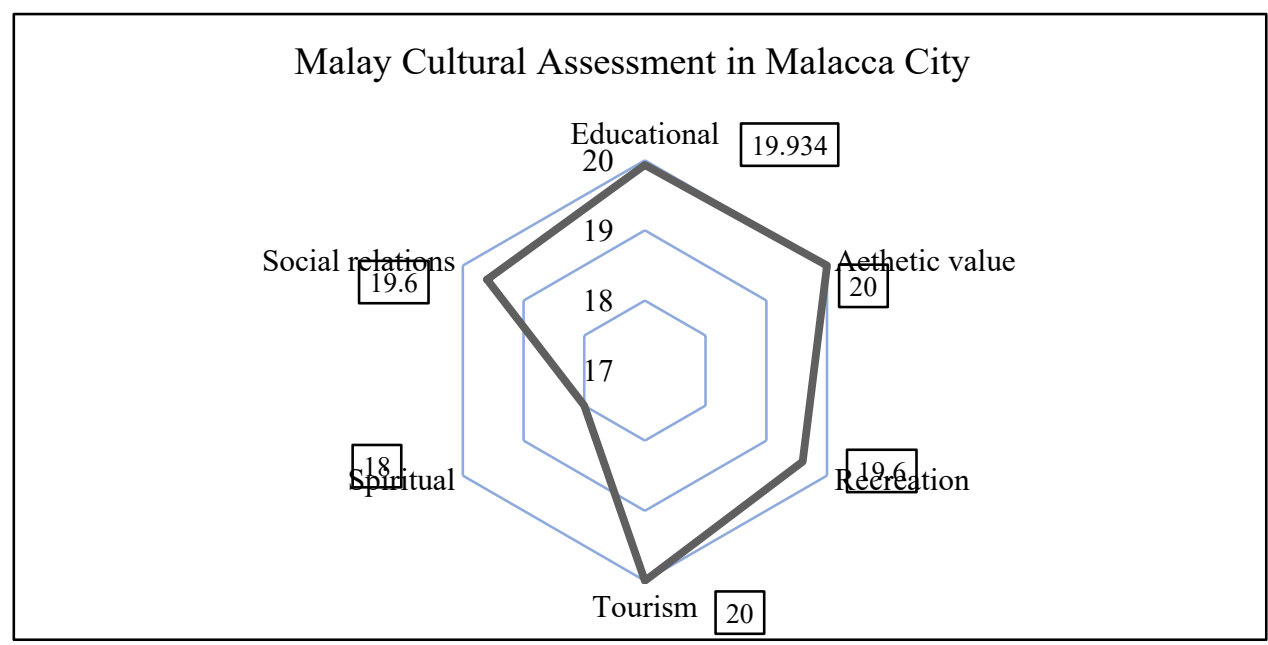

Figure 2: Malay cultural assessment in Malacca City

The level of respondents' cultural satisfaction was measured and analyzed from the survey data. Then, the figure shows that the highest level of satisfaction among the cultural services is in the aesthetic value and tourism services with a value of 20 respectively, followed by educational services with 19.93, both recreational and social relation services have the value of 19.6 and spiritual services have the value of 18 . The cultural ecosystem services are defined in the report of the Millennium Ecosystem Assessment (MEA) as "nonmaterial benefits the people obtain from ecosystems through spiritual enrichment, cognitive development, reflection, recreation, and aesthetic experiences" (MEA, 2005a:40). 
Nur Shazwanie Rosehan, Azlan Abas, Kadaruddin Aiyub

Studies on Malay Urban Ecosystem Services and Cultural in Malacca City

\section{DISCUSSION}

Overall, the paper gives a summary of all aspects that are related to this Malay urban studies including the concerns of current studies that are related to the Malay urban design and urban ecosystem services. There are several problems and challenges that need to be faced while carrying out this study. In the area of data collection in the field, namely the distribution of questionnaires, the problems and the main challenges are the difficulty to get the Malay respondents to complete the questionnaire. Besides, many respondents did not understand the term and key variables in this study of the urban ecosystem services and the Malay cultural services. Therefore, the researcher should take a considerable amount of time to inform the respondents before they complete the questionnaire form.

Based on the findings, Malacca City provided good Malay urban ecosystem services which were the regulating services i.e. climate regulation, flood regulation, disease control, carbon sequestration, noise pollution reduction, then supporting services i.e. hydrology cycle and cultural services i.e. spiritual, recreational, tourism, aesthetical value, educational and social relations. However, no service from provisioning services seems important because its services were rare, and none is offered directly in the urban ecosystem services. Based on this, the attempt to generate a liveable and sustainable city, including a Malay urban design that is complete with all the good infrastructures, social activities and interests, green landscapes, human security, social safety and protection, residents, public health, education and social work; shows the sustain process and usually needs enhancement (Khalid, 2016).

Based on the questionnaires that have been answered by the respondents, most of them were agreed that they got benefits in the educational services categories in Malacca City. For example, 'the residents are easy to access in education and a variety of facilities are available in channeling knowledge" questions which mostly got the highest score $(85 \%)$ among the respondents. Education, that interest in the quality of living that connected to people living and allows people to make better decisions with their valued outcome (Ayoroa et al. 2010). Tourism's impact on the socio-cultural identity of the community such as introducing unique to foreign tourists also showed the highest score (90\%) among the respondents. Based on this, Malacca City has ventured as an educational urban and tourism. It was supported by a studied that done by Samsir et al. (2016) and stated that tourism products in Malacca have valuable knowledge and experience for communities and tourists.

Next, in the categories of spiritual services, for example, the respondents feel free to go to a place of worship without hindrance and more facilities related to worship provided in the residential area also scored the highest percents $(88 \%)$ among the respondents. For example, the mosque can be found anywhere in the city or village with the uniqueness of the architecture and 
attraction design (Abdullah 2012). Furthermore, based on aesthetic value services in Malacca City, some landscapes have a high aesthetic value and quality in the vicinity ( $82 \%$ scores) and the historic building has a role in the cultural landscape also got the highest scores (79\%) among the respondents. It connected with the studies that Malacca is a popular tourism terminus and destination that rich with cultural attraction and historical heritage which also offers knowledge and educational opportunities to various communities including Malays and visitors (Samsir et al. 2016).

As reported by Elmqvist et al. (2015), cities are a key nexus of the relationship between people and nature and are the huge centers of demand for ecosystem services and also generate extremely large environmental impacts. It can be seen based on the results that Malacca City was a convenient city and good in providing the urban ecosystem services, especially towards Malay's communities. While the city can provide many benefits and services to humans through the development and urban expansion activities, however, it remains an adverse impact on the environment. Thus, maintaining and increasing the providing of various ecosystem services, are relevant and significant in both perspectives of human living and the economic such as non-marketed and nonmonetary services (Loinaz et al. 2015). This is important for the Malay urban dweller and communities who are surviving in the urban area in long duration and to make sure that their quality of life is in a good condition including in the cultural services. According to Ali et al. (2010), urban dweller's quality of life is very much depending on the livability of the city and people tend to leave the city when it has become less livable.

Based on the assessment of Malay cultural services in Malacca City, the study found that several aspects should be taken seriously by the authorities such as MBMB. For example, the authorities should play their roles in providing social infrastructures such as in maintaining the natural environment in the recreational area that can be used by the communities safely. Furthermore, the other cultural services in Malacca City that should be monitored from time to time, is to make sure that all the repairs, conservation and perhaps some improvement on the facilities aspect to be conducted immediately. It can be related with Riechers et al. (2016) who reported that the cultural ecosystem services could be one way to achieve awareness on the socio-ecological aspects, as the results show that there are linkages between cultural ecosystem services and urban social sustainability. Therefore, it is necessary to ensure that a Malay city is primarily a sustainable, liveable and securable, without having to sacrifice different and various natural resources and its UES. This is to make sure that the Malaysian policies should focus especially on the needs and class of Malay society, even within the same ethnicity. For example, the scholarships for overseas still need to be given as the majority of Malays parents are not able to cope with their child's learning and many education accesses needs to be 
Nur Shazwanie Rosehan, Azlan Abas, Kadaruddin Aiyub

Studies on Malay Urban Ecosystem Services and Cultural in Malacca City

improved. Next, the SDG's goals as planned will be achieved as all the countries comply with the policies such as the Paris Agreements, and hence the standard of urban ecosystem services would be allowed to enhance in the future.

Studies on the urban ecosystem services and urban design have received increasing attention from researchers covering various aspects such as the study of culture and the benefits of its services, especially to humans and the environment. Therefore, there are several research proposals for future research. In this study, the researchers emphasize the cultural aspects of the Malay population in the city of Malacca. In the next study, the researcher intends to broaden the scope of the study area to include a broader range of aspects and scopes. In the context of data analysis, the researcher uses only a simple descriptive analysis, therefore in future research, the researcher intends to diversify the data analysis method so that various data inputs can be presented and discussed in detail. For example, a statistical analysis such as the Correlation Test and the Manova test can be utilized. So, the studies on aspects of urban ecosystem services and each category are relevant for implemented to ensure that urban areas with variety of ethnic groups including Malay communities will live safe, habitable and sustainable time by time.

\section{CONCLUSION}

The study has given an overview on Malay urban ecosystem services and Malay cultural in Malacca City that related to variety of benefits provided by the environment especially to the community and economy for maintaining human well-being. Overall, based on the result and the studies, the most significance of the urban ecosystem services provided by classified them, including cultural services (aesthetic value, recreational, tourism, social relations, spiritual and educational), regulating services (climate regulation, disease control, flood regulation, carbon sequestration and noise pollution reduction) then followed by supporting services (hydrological service). Finally, the paper concludes that the level of satisfaction among respondents toward the urban ecosystem services that have been offered in Malacca City is moderately good, but a few adjustments and improvements are in need immediately. So, all the parties should play an important role to make sure the cities especially Malacca City keep sustainable and more livable with the right policies and guidelines efficiently.

\section{ACKNOWLEDGEMENTS}

This study was supported and funded by Centre for Research and Instrumentation (CRIM), Universiti Kebangsaan Malaysia (UKM) from the Geran Universiti Penyelidikan (GUP) research grant (GUP-2018-032). 
PLANNING MALAYSIA

Journal of the Malaysia Institute of Planners (2020)

\section{REFERENCES}

Abdullah, N. F. (2012). Masjid Sebagai Pengendali Penginapan: Kajian Kes Di Masjid Al Ghufran, Selangor. Conference: Tourism and Hospitality International Conference (THIC 2012).

Ahern, J. (2007). Green infrastructure for cities: The spatial dimension. Conference Cities of the Future: Towards Integrated Sustainable Water and Landscape Management. IWA Publishing.

Abdullah, A. A. A., Mohd Noor, N. \& Abdullah, A. (2018). Drone 3D mapping in identifying Malay urban form: case study of Kota Bharu. IOP Conference Series: Earth and Environmental Science, 169.

Ali, H., Rashid, N. H. A., Lukman, Z. M. \& Awang, A. (2010). Socioeconomic wellbeing and the quality of life between regions: A case of Malaysia. International Business Management, 4(4), 250-254. https://doi.org/10.3923/ibm.2010.250.254

Ayoroa, P., Bailey, B., Crossen, A. \& Geo-JaJa, M. A. (2010). Education in China: The Urban/Rural Disparity Explained in Zajda. J. (ed.), Globalisation, Ideology and Education Policy Reforms, Globalisation, Comparative Education and Policy Research 11, Globalisation, Ideology and Education Policy Reforms, 89-113.

Corbera, E. (2012). Problematizing REDD + as an experiment in payments for ecosystem services. Current Opinion in Environmental Sustainability, 4(6), 612619.

Costanza, R., D’Arge, R., De Groot, R., Farber, S., Grasso, M., Hannon, B., Limburg, K., Naeem, S., O’Neill, RV., Paruelo, J., Raskin, RG., Sutton, P. \& Vandenbelt, M. (1997). The value of the world's ecosystem services and natural capital. Nature International Journal of Science, 387 (1997), 253-260.

De Groot, R., Ramakrishnan, P. S., Berg, A.V. D., Kulenthran, T., Muller, S., Pitt, D. \& Wascher, D. (2005). Chapter 17: cultural and amenity services. Pages 455-476 in Hassan, R., Scholes, R., Ash, N., Ecosystems and human wellbeing: current state and trends, volume 1. Findings of the Condition and Trends Working Group of the Millennium Ecosystem Assessment.

Dewan Bandaraya Kuala Lumpur. 2020. Kuala Lumpur Structure Plan (2020) in Urban Design and Landscape.

http://www.dbkl.gov.my/pskl2020/english/urban_design_and_landscape/index.

Egoh, B., O'Farrell, P., Charef, A., Gurney, L. J., Koellner, T., Abi, J. N., Egoh, M. \& Willemen, L. (2012). An African account of ecosystem service provision: use, threats and policy options for sustainable livelihoods. Ecosystem Services, 2(2012), 7181. https://doi.org/10.1016/j.ecoser.2012.09.004

Eliasson, I., Knez, I. \& Fredholm, S. 2019. Heritage Planning in Practice and the Role of Cultural Ecosystem Services. Journal Heritage \& Society, 11(1), 44-69. https://doi.org/10.1080/2159032X.2019.1576428

Elmqvist, T., Setala, H., Handel, S. N., van der Ploeg, S., Aronson, J., Blignaut, JN.,

Gomez-Baggethun, E., Nowak, DJ., Kronenberg, J. \& de Groot, R. 2015. Benefits of restoring ecosystem services in urban areas. Current Opinion in Environmental Sustainability, 14,101-108. https://doi.org/10.1016/j.cosust.2015.05.001.

Gonzalez, M. J. \& De Lazaro, M. L. (2011). Urban Development and Sustainability. European Journal of Geography, 2(1), 38-50. 
Nur Shazwanie Rosehan, Azlan Abas, Kadaruddin Aiyub

Studies on Malay Urban Ecosystem Services and Cultural in Malacca City

Khalid, K. A. T. (2016). Konsep, dasar dan perlaksanaan Bandar Sejahtera dengan rujukan khas kepada Malaysia. Malaysian Journal of Society and Space, 12(7), $26-33$

Md Jahi. J. (1993). Issues of Environmental Management through Legislative Measures in Malaysia. Akademika, 42 (1), 181-204.

Milcu, A. I., J., Hanspach, J., Abson, D. \& Fischer, J. 2013. Cultural ecosystem services: a literature review and prospects for future research. Ecology and Society, 18(3), 44. http://dx.doi.org/10.5751/ES-05790-180344

Millennium Ecosystem Assessment Series. Island Press: Washington, D.C., USA.

Millennium Ecosystem Assessment (MEA). 2005. Ecosystems and Human Wellbeing: Synthesis Report. Island Press: Washington, DC.

Müller, F. \& Burkhard, B. (2012). The indicator side of ecosystem services. Ecosystem Services, 1(1), 26-30. https://doi.org/10.1016/j.ecoser.2012.06.001

Riechers, M., Barkmann, J. \& Tscharntke, T. (2016). Perceptions of cultural ecosystem services from urban green. Ecosystem Services, 17(2016), 33-39. RodríguezLoinaz, G.,

Josu G., Alday, J. G. \& Onaindia, M. (2015). Multiple ecosystem services landscape index: A tool for multifunctional landscapes conservation. Journal of Environmental Management, 147(2015), 152-163. https://doi.org/10.1016/j.jenvman.2014.09.001

Samsir, S. W., Ahmad, H., Choy, E. A., Jusoh, H. \& Mat Jali. M. F. (2016). Meneroka Edupelancongan Di Melaka Bandaraya Warisan Dunia Berasaskan Pengalaman Pelancong Domestik. Malaysia Journal of Society and Space, 12(11), 156-167.

Sarukhán, J. \& Whyte, A. (2003). Ecosystems and human well-being: a framework for assessment. Millennium Ecosystem Assessment Series. A report of the Conceptual Framework Working Group of the Millennium Ecosystem Working Group. Island Press: Washington: Island Press.

The Economics of Ecosystems and Biodiversity in National and International Policy Making. (2011). Edited by Patrick ten Brink. Earthscan, London and Washington.

Tratalos, J., Fuller, R. A., Warren, P. H., Davies, R. G. \& Gaston, K. J. (2007). Urban form, biodiversity potential and ecosystem services. Landscape and Urban Planning, 83(4), 308-317. https://doi.org/10.1016/j.landurbplan.2007.05.003

Van Oudenhoven, A., Petz, K., Alkemade, R., Hein, L. \& de Groot, R. (2012). Framework for systematic indicator selection to assess effects of land management on ecosystem services. Ecology Indicator, 21, 110-122.

Zhang, Z. M., Gao, J. F., Fan, X. Y. \& Lan, Y. (2016). Assessing the variable ecosystem services relationships in polders over time: a case study in the eastern Chaohu Lake Basin, China. Environmental Earth Science, 75(856), 1-13. https://doi.org/10.1007/s12665-016-5683-5 